\title{
Banks and Fintechs: How to Develop a Digital Open Banking Approach for the Bank's Future
}

\author{
Anna Eugenia Omarini ${ }^{1}$ \\ ${ }^{1}$ Bocconi University, Department of Finance, Via Roentegen 1 - 20136 Milano, Italy \\ Correspondence: Anna Eugenia Omarini, Bocconi University, Department of Finance, Via Roentegen 1 - 20136 \\ Milano, Italy.
}

Received: June 29, 2018

Accepted: July 27, $2018 \quad$ Online Published: August 10, 2018

doi:10.5539/ibr.v11n9p23

URL: https://doi.org/10.5539/ibr.v11n9p23

\begin{abstract}
Mutated market conditions, the advent of new players and digital technologies, and a significant regulatory push, are profoundly changing the banking industry. Banking business models may shift significantly from a pipeline, vertical, paradigm, to open banking models where modularity can be an opportunity for banks. Not only are the abovementioned factors representing a threat to the traditional model, but also they are spurring significant new opportunities to pursue new revenue streams. Those opportunities are exploited through new banking paradigms that entail higher levels of openness towards third parties and a crescent number of modular services bundled together. Models can go to mere compliance with the prescriptions of openness of PSD2, to the inclusion of new services, the opening of the banking core and data, and the aggregation of those within a platform experience. Value is created in platforms through economies of scope in production and innovation.

This paper has explored the evolution of Fintech and Techfin in the market and the emergence of platform models in banking. It has investigated the evolution of that concept, also introducing an interesting banking case (BBVA), which gives several insights on the choices made toward a Banking-as-a-Platform model within the context of Fintech and Open Banking.
\end{abstract}

Keywords: digital transformation; FinTech; Techfin; retail banking; open banking; business model; open innovation; platform

\section{JEL: G20, G21, G28}

\section{Declarations of interest: none}

\section{Introduction}

New trends are constantly appearing in the market; some of them can be good for banks, while others may appear not being so good. In this new emerging context, there are many dynamic changes to look at and be ready to face, and a strategic plan is fundamental to getting ahead, so that each retail bank should develop its own version of the future, according to its strengths, weaknesses, and constraints. Each economic choice has its own constrains and this occurs when an agent must determine the optimal combination of choice variables (given some relationship between combinations of those variables and payoffs) in the face of a constraint limiting the set of feasible combinations for those variables available to the agent. This situation also arises when agents must make forward-looking decisions or when they are uncertain about the future (Mas-Colell, 1995). This is the case for retail banks, whose future lies in the needs of their customers, which are under important changes. Sometimes banks have seemed schizophrenic, and one of their weaknesses lies in lagging an effective execution of a real market-oriented strategy (Omarini, 2016). Given that, banks have become less central to their customers' everyday lives, while other businesses are eyeing banking activity with major interest, sizing up any potential gaps in the market for themselves. From this situation, we gather an important message to outline, which is that banking is not in search of relevance in the economy. The issue instead moves on the output for a better service, because only a better service always leads to more sales; and this becomes even more important when an economic agent sells services, as it is the case for banks (Omarini, 2015). On this same issue, Fintech and Techfin companies' missions have been inspired so that they have both decided entering the market. Given that, banks have to regain their market position and set out all their capabilities to help customers meet their life events and opportunities, rather than just supplying the many components for them to build solutions. 
This work has its premises in this situation of change and collocates itself in the position to shed a light on the need for an effective strategic repositioning of banks' strategies, taking advantage of the scale of banks from one hand, and the evolving digital ecosystem (Microsoft Services, 2017) on the other hand. The challenge is to keep the entire 'customer game' inside the retail bank, and this can be possible under certain conditions.

There is a number of innovations, which are gaining real traction in the market, from a technology perspective. Cloud, particularly Platform as a Service (PaaS) and Software as a Service (SaaS) are lowering the barrier to sophisticated financial applications by allowing people and talent to focus on business value added tasks as opposed to the building, supporting and managing of infrastructures. Advanced Artificial Intelligence (AI) and Machine Learning techniques are allowing data scientists and researchers to reveal non-obvious patterns in complex, high dimensional data. Internet of Things (IoT) is also allowing real-time sensors to assess businesses and assets financed continually, and create new partnerships between them. All this, and more, regards the changes that Open Banking will bring with it, and they may encourage switching and comparison, with improved results and product offerings for consumers. Also encouraging consumers to share information with third party providers to get the best possible deal, move, manage and make more of their money and giving individuals more control over the data they share; attracting and retaining customers is going to become even more important for financial institutions.

Given that banks have to move from running their business to change the bank, because many insights tell that, the way banks operate may be disrupted from certain points of view, so that now for banks there is a wake-up call.

The aim of this work is two-fold: describing why Fintechs and Techfins entered the market (paragraph 2); and exploring the themes and economics relating to a digital open bank approach (paragraphs 3 and related). In this regard, a managerial perspective is given to outline the changes needed to move from running to changing a bank. Because leading banks will go a step, further than the competition and transform the bank-client relationship models. To exploit an example on this direction, we develop a brief analysis of the banking case of BBVA (paragraph 4 and related), as an interesting example of a bank-Fintech collaboration. Finally, in paragraph five conclusions and implications have been outlined.

\section{Fintech and Techfin: Different Perspectives Move Their Entering the Financial Market}

According to Arner, Barberis \& Buckley (2015) the label Fintech entered the market as the employment of technology to provide financial services. Blake \& Vanham (2016) refer to Fintech as the use of technology with respect to the design and provision of financial services. In addition, (PwC, 2016, p. 1) describes the word "Fintech" (contraction for Financial Technology) as the evolving intersection of financial services and technology. In the past, the term was used to merely indicate the technology embedded in the backbone of financial institutions; however, now it encompasses any innovation in the financial services industry (Investopedia, 2017).

A broader definition of Fintech comes from the Financial Stability Board (FSI, 2017, June 27), which describes Fintech as follows: technologically enabled financial innovation that could result in new business models, applications, processes, or products with an associated material effect on financial markets and institutions and the provision of financial services.

The Fintech notion relates to disrupting start-ups (henceforth, also labelled as Fintechs) (Chishti \& Barberis, 2016). While for the diversified tech giants (e.g. Google, Amazon, Apple, Alibaba, etc.) the definition is that of Techfins.

According to the European Banking Institute - EBI - (Dirk A. Zetzsche, 2017) Techfins start with technology, data, and access to customers. Then they move into the world of finance by leveraging their access to data and customers and seek to out-compete incumbent financial firms or FinTech startups. By selling the data to financial services providers or by leveraging its customer relationships by serving as a conduit through which its customers can access financial services provided by a separate institution, they could develop later a different strategy by providing financial services directly itself.

This is the critical distinction between a Techfin and a Fintech startup compared to a traditional financial institution, such as a bank, which typically starts with a banking relationship with customers and have only recently even begun to consider supplementing their risk analysis of customers by using more broadly derived data.

Often, the services offered by Fintechs are perceived as of better quality, more convenient, and richer in choice (PwC, 2016; PwC, 2017a; EY, 2017). In this environment, new models have populated the market, with an offer 
that has never been so rich. It is with this respect that Fintech has brought to the traditional banking industry a wave of competition and would be able to break pipeline value chains (KPMG, 2017), unbundling them into different modules of products or services, which can be developed among themselves. As a result, EY (2017) found that, nowadays, at least a third of consumers of digital products use a minimum of two Fintech services, demonstrating the appetite for new technologies, especially in niches that previously found it difficult or not convenient to access banking services.

Nowadays, almost 90 per cent of the banking executives think that they could somehow lose business to disruptors (PwC, 2017a). The bottom line of this is that banks have increasingly focused on technological aspects and on the use of new technologies in financial services (Omarini, 2018).

The digital transformation is not really a pure technological revolution. Indeed, it is the driving force of the new industrial revolution, which concerns the development of new information and communication technologies, where the increased usage of digital devices and digital platforms are transforming the way customers do their banking, change market expectations, and are going to transform the model of financial intermediation as well (Dhar \& Stein, 2016). Consequently, the digital evolution seems to make retail banks, in particular, inevitably become victims of disintermediation as more activities become available online, and technology started breaking up value chains. So that strategists could no longer take their value chains as a given: they had to make hard choices about which parts of them to protect, which to abandon. However, on this hand the picture is not necessary completely bleak for banks. They perform several functions, and computer networks (i.e., their safe deposit business, where new entrants were less interested in offering them at the beginning) will affect not all of them; notwithstanding their business model (See Box 1) should change. Overall, if we consider that the advent of Internet and the technological changes have played a major role in the recognition of the relevance of an explicit business model, mainly due to the strategic choice of many dot-com of using it as an instrument for gathering funds.

Box 1. Business Models in a nutshell: a bank perspective

The terminology "business model" was first used by Drucker in his "The Practice of Management" (1954) through which he irreversibly perturbed the history of managerial studies by recognizing the importance played by the external environment on the proactive managerial activity of choosing the way a company should be designed. According to Itami \& Nishino (2010) a business model has two elements worth outlining and they are the business system and profit model respectively. Although, generally people focus on the profit model because it looks more important due to the fact that it is more visible and directly related with money generation, the business system is actually the key element, which is designed with the aim of defining the way the goals will be achieved. It can be decomposed further into two more elements: the so-called learning system and the delivery system (either internal or external). The core invisible assets (or capabilities) of a firm delineate its profile - by setting its boundaries - and determine the current delivery system which, through the learning system, provokes the evolution of invisible assets in the future, and thus a new business system will be designed according to the relation between the two. This interdependence between current capabilities and the business system explains the reason why dynamism is important when talking about business models and innovation. As stated by (Teece, 2010), business models are situational and they are originated through an iterative process which allows exploiting learning, for instance drawing inspiration for the design of a new or renewed business model from other sectors, or competitors.

The business model itself can be a competitive advantage if it is coupled appropriately with business strategy, conditional on it being able to convey value propositions, which are relevant to customers and capturing value by means of superior cost and risk structures. Moreover, a business model cannot be competitive in the long run, if externals can copy it easily. For this, it should contemplate an isolating mechanism, which can be in the form of hard-to-replicate systems or assets, general opacity of the model, or simply high degree of cannibalization hindering incumbents' trial to adopt the new business model for their own activity.

Moving into banking literature on business model analysis, there is some interesting literature with a particular regulator's perspective, which takes into consideration, overall, the issues for a bank to be stable and resilient to market shocks. This means putting a major attention on the degree and kind of diversification a bank develops such as entering different businesses, such as retail banking, corporate banking and investment banking. In particular, the ECB study on business models published in the Special Features section of the Financial Stability Review (2016) is an empirical analysis on Banking Business Models (BBMs). Nevertheless, the most referenced studies on BBMs are those redacted by Ayadi et al. (2011) (2012) (2014) (2015) with the aim of identifying the exact number and composition of different Banking Business Models in the European environment. Ayadi's 
papers aim at spotting the different BBMs based on the nature and scope of banks' funding strategies and the performed activities by employing statistical procedures. Given that, Ayadi et al. classified into five groups of banks by differentiating from one another for their activities being more or less market-oriented and their funding structure. Three of the five clusters refer to banks performing retail-oriented activities - namely one cluster considers banks focusing on deposit-taking and lending activities, another cluster was based on the customer deposit taking and trading activities. Finally, the third group of retail-oriented banks is active in trading but differs in funding strategy, with heavy reliance on debt liabilities. The remaining two clusters are the wholesale banks - performing bank-intermediation activities - and investment bank - characterized by trading and investment-oriented activities. A recent paper on BBMs is made by European Banking Association (EBA) (Cernov \& Urbano, 2018, June), which offers a structured and consistent approach to regulatory impact assessment, analyzing trends and risks, proportionality, and supervision, so to ensure the continuity and comparability of results over time.

Given all that above, it is clear that the perspective has a little approach on a pure bank strategy market positioning (Omarini, 2014).

Digitization of products, services, and business processes allow disruptive players to assemble and deliver the same, but also a new set of value a traditional competitor provides - and even augment it — without having to reproduce the whole conventional value chain. In fact, that is the objective of digital disruption (Citibank, 2016): to provide superior value to the end customer - either a consumer or another business-while avoiding the capital investments, regulatory requirements, and other impediments of encumbered incumbents with a new and different business model (de Jong \& van Dijk, 2015) (Omarini, 2018). The prerequisite of letting this to become possible lies on the fact that the components of the Internet revolution are "just bits", which become software, protocols, languages, and capabilities that can be combined and recombined in ways to create totally new innovations. These immaterial components make simple to spread them around the world, and so develop a huge number of innovations. The most successful disruptors employ "combinatorial disruption," in which multiple sources of value - cost, experience, and platform - are fused to create disruptive new business models and exponential gains (Varian, 2001). This can also be synthetized as open innovation In literature open innovation has widely described as process offering its benefits in terms of effectiveness -using more outside ideasefficiency - specialization and economies of scale and scope, cost and risk sharing (Chesbrough, 2003; Chesbrough, 2006; Enkel, Gassmann, \& Chesbrough, 2009; Chesbrough, 2011; Chesbrough, Vanhaverbeke, \& West, 2014). In other words open innovation in brief implies that a firm uses both internal and external ways to create new products (Chesbrough, 2011), and increase flexibility in the way it can provide a market request on time (Schueffel \& Vadana, 2015) and easily tailored it to its customer's tastes. The ability to innovate becomes a strategic prerequisite for the financial services industry's growth and success and the adoption of open innovation practices can foster collaboration and facilitate the rethinking of the industry's existing business model and value proposition, within an increasingly complex and volatile world. Given that, each financial institution should show willingness to understand the people primarily, and the individual working relationships, along with organizational values, visions, strategies and place in the market (Mention \& Salampasis, 2018).

Given all that above, we think the main forces shaping these changes have led the industry to reconsider the role of banking and finance, more as a strategic "enabler" than a provider of products and services. We think the main reason for this shift in the role of banking and finance lies on the fact that bank and financial services rely heavily on the transformation and management of information (on accounts, on balances, on asset classes, etc.), through which for many years banks have been able to lower transaction costs for their customers (Deutsche Bank, 2014). Modern technologies, overall based on the digital paradigm, have made the role of traditional banks outdated, as most of this information is processed more easily and at a greater efficiency, further lowering transaction costs with respect to banks. This means for banks to change their strategic perspective and work on increasing value for their stakeholders, among which customers play an important role, at present.

\section{The Shifting Paradigm of Banking from Unbundling to Re-Bundling Services: New Business Opportunities Are Arising}

At present, we can outline two mainstreams in the banking arena; the first one regards the paradigm of banking, which will move more and more on digital premises, so to make it modular and flexible to face diverse and changing customer's needs. Chen et al. (2017) use the concept of technology power as technology is going to be the most relevant element in competition within banking.

During this stage, technology in banks is overall used to develop a renewed bank-customer experience. Consequently, banks have invested huge sums in technology -automating processes and enabling customers to 
bank online throughout different devices- but this has not seen the fundamental transformation of business models yet, the ones that had taken place in other sectors, such as music. This will happen in banks as well, and when it does, it will have a huge impact on the financial intermediation model. Some of the consequences are clear from other industries. Intermediaries disappear or are marginalized unless they discover new ways of adding value. Look at what has happened to recorded music companies or bookshops. What is going to happen in the financial system in three to five years, and how it is going to change its intermediation model, is not fully clear yet. What is well known is that banks, which are the primary intermediaries of the financial world, are experiencing sharp and further reduction in their margins unless they reinvent what they offer their customers and how they work. Linked to this, there is the second stream of changes, which seems being less visible now. Banking, as of today, is shifting from a universal model -where economies of scale, scope and some conflict of interests have risen in the market - to a new wave of bundling of services and business models from third-party companies, all of them focused on customers and not on what banks, or any single financial institution, may sell to the market.

Once Fintech have entered the market, the market has experienced a wave of unbundling, which has brought to the traditional banking industry with a consequence of changing the game of competition, because they were able to break pipeline value chains, unbundling them into different modules of products or services, and combine among themselves. In addition, because the services offered by Fintechs are perceived as of better quality, more convenient, and richer in choice (PwC, 2016) (PwC, 2017a) (PwC, 2017b) (EY, 2017), as well as perceived to be more transparent from a customer's perspective, then the customer's choice has become the issue for each business model in the market arena (Magretta, 2002) (Omarini, 2015). The main result coming from this situation, nowadays, is that at least a third of consumers of digital products use a minimum of two Fintech services (EY, 2017), demonstrating the appetite for new technologies, especially in niches that previously found it difficult or not convenient to access banking services. Given that, Fintech firms are earning reputation for customer-centricity by bridging the gap between what financial services currently offers versus what today's customer want.

Moreover, behind the unbundling process undertaking in the financial industry there is a strategic risk for banks. The potential for rapid unbundling of bank services to non-bank Fintech or Techfin firms increases risks to profitability at individual banks, since the beginning and in the end a decrease institutional stature of banks into the everyday customers' life. Existing financial institutions stand to lose a substantial part of their market share and/or profit margin if new entrants are able to use innovation more efficiently, deliver less expensive services that may meet customer expectations better, and overall develop a more personalized and time to market answers to customers. At this point, however, it is worth outlining that, at present, behind most of Fintech companies lies conventional infrastructure, and/or components of the traditional banking value chain (think of clearing and settlement for payments, credit bureau for lending, etc.). (Brainard, 2017)

In today's environment, a disruptive deterioration of profitability due to the loss of profitable direct customer relationships and/or margin compression might weaken the ability of incumbent institutions to weather future business cycles, for example, if banks react to falling profits by engaging in riskier activities, such as moving down the credit spectrum.

All this above is a part of the big picture, which is going to take its evolution over the next few years, thanks to new technologies and dynamics in banking (Broeders \& Khanna, 2015), along with the nascent surrounding ecosystem, which spur anyway significant opportunities for the most responsive and market-oriented players. Given that, banks and new actors can meaningfully cooperate in order to innovate and compete within the industry. While the acceleration towards an open industry has provided by regulation (such as the Payment Service Directive - PSD2), at the same time, proactive approaches towards an open paradigm, which can be a successful move for banks trying to take advantage of the nascent digital ecosystem and follow the market. In between mandatory requirements and full openness with sophisticated Application Programming Interfaces (APIs), and in between few and a diverse range of products and services involved, lies a whole set of choices about the level to which banks decide to collaborate with other firms. APIs show to be the heart of Fintech revolution, this is because they affect the way in which customer consume products and services online, and also the way of working and understanding the corporate world. Furthermore, the API does not stop being a source of data for a third party, because it lets each one being in the system to access and use its information. The added value is that each bank or financial institution can access a lot of data sources that generate a large volume of information that is as valuable as it is unwieldy. Given these opportunities the second wave of role of Fintechs in the market moves from being disrupters to partners, infect some Fintechs in the market have started a framework of collaboration with incumbents, whose infrastructure, regulation expertise, scale and trust are useful. The most proactive banks can try to monetise on what PSD2 at the European level, but similar open banking regulatory 
frameworks can be found in other countries as well. This stream of regulation mandates and construct paradigms characterised by efficiency, new products and services, and enhanced use of data. However, the set of options for banks for reinventing themselves has no limitations except for the single banks' constrains. All this is indeed an attempt to be at the centre of an open landscape in which products and services can be delivered through interaction within a broad ecosystem, also aggregating a diverse offering to provide significant value to match the demand conditions in the market.

Executives within banking stressed the concept of openness as an opportunity to be the first point of contact with the customer in a wider array of services, hence targeting cross- and up-selling (Finextra \& CA Technologies, 2016). However, we think that the value of Fintechs to partner with banks or other financial institutions is far beyond that of being a better customer gateway. An example of framework coming from this collaboration, is outlined by KPMG (2017, p. 24), when they outline Fintechs:

1. Enable access for customers that were previously excluded from the traditional financial system by enhancing infrastructure, innovating in new products, lowering costs and allowing them to enjoy the same standards of services as other customers.

2. Are able to analyze customer data to offer personalized services, and provide more interactive communication through multiple channels, significantly increasing customer engagement and experience.

3. Enable aggregation of products/services and data, providing information on choices, coverage and pricing of products and services, enhancing fair customer outcomes.

4. Through use of data analytics and other technologies, offer possible solutions to improve security, mitigate risks and streamline compliance processes (RegTech).

5. Thanks to the use of AI and data analytics have enabled these companies to provide tailored customer support and guidance in a cost effective way. They help customers develop financial knowledge and good saving and spending habits.

\subsection{The Paradigm of Open Banking in the PSD2 Framework: in a Nutshell}

The advent of PSD2 has opened many of the payment and banking industry services to third parties and constituted a threat to revenue streams deemed as certain. This piece of regulation shifted indeed the intellectual property on data from banks to customers. The pipeline business model was threatened by the emphasis that PSD2 put on services, which could be sold by any recognised provider, rather than only by the bank in possession of account information.

PSD2 has opened the banking sector. Now banks are mandated to be able to provide access and to communicate, to authorized third parties, customer and payment account information. Within this framework, banks set up open interfaces, namely APIs, in order to ensure they are fully compliant. However, besides the mandatory prescriptions of PSD2, there is a whole span of choices that banks can select in terms of openness and services involved. This aspect has given substance to the notion of "Open Banking". This approach relates to Open Innovation literature to the extent that banks rely on the flow of inside and outside ideas to develop products and services, and innovative processes (Chesbrough, 2003; Chesbrough, 2011). However, also existing products and services are provided in new ways and in collaboration with third parties, an additional fact that creates the premises to define an entire ecosystem around the concept of Open Banking. Banks can select the level of openness and the type of value they want to provide according to business and demand, organizational, and capital expenditure considerations. In addition, banks can select to integrate their offering in the business model of other players. Overall, what matters is the openness of the paradigm, in which the bank interacts within the surrounding ecosystem.

In this sense, the work of Cortet, Rijks, \& Nijland (Cortet, Rijks, \& Nijland, 2016) was relevant as they identified four different strategies that specifically address Open Banking models that a bank may pursue in a PSD2 context; and they are:

- Comply. The bank opens information only to the extent it is mandated to do so. In here, there is a strong reconsideration of the value proposition. Traditional revenue streams that were deemed as certain are impacted, third-party interfaces disintermediate the bank. In here, banks retain their role as an account service provider and backbone of the system. 
- Compete. Banks react and, besides compliance, they try to fight for customer proximity through their own interfaces, with the implication of rethinking the overall model in terms of value proposition, processes, costs, revenues, and channels.

- Expand. This strategy goes beyond exposing basic account information. Banks can expose open APIs and pursue new revenue streams, especially from providing full account information and specific services, such as data management and identity verification, to third parties. In here banks become the gate through which third parties can access data and other services.

- Transform. This is a specific subset of Open Banking, where a platform strategy can take its implementation. In here banks offer specifically a core around which other players can build their offering, in addition to connecting users across different groups, facilitating matchmaking. With this model, there is a radical re-thinking of the business model. Banks indeed also try to monetise APIs as well as competing and profiting from an own enhanced value proposition to customers, fulfilling shifting market needs.

It appears evident that all of the four strategies entail some rethinking of the overall banking business model intended as processes and value proposition, customer segments, revenues and costs, channels and distribution, external interaction and co-operation - in the direction they are addressing (Osterwalder, 2013; Cortet, Rijks, \& Nijland, 2016), as well as governance and internal organisation. Indeed, the Open Banking model fostered by PSD2 take advantage specifically from APIs. The traditional account relationship becomes the basis for offering a broader array of services - rethink value proposition, segments and revenues - from bank and non-bank players - rethink external co-operation - in a more efficient guise - rethink costs - and through either bank or non-bank new interfaces - rethink channels of contact.

Similarly enough to Cortet, Rijks, \& Nijland (2016), consulting literature has widely dealt with Open Banking models, (see for example PwC, 2017b; Deloitte, 2017; Brodsky \& Oakes, 2017). In paricular, PwC (2017b), has classified Open Banking models according to value added and level of openness selected by banks. That resulted in a scenario where banks could adopt models entailing (See Figure 1):

- Compliance with PSD2 through minimum openness at the mandated levels and low value added in terms of proposition (similar to the "comply" strategy).

- Low openness and high value added with new proprietary services and functionalities developed (similar to the "compete" strategy).

- Maximum openness and low value through providing enhanced data and information to third parties (similar to the "expand" strategy).

- Maximum openness and high value through providing advanced data and information, allowing for third-party applications to be embedded within the core functionalities and taking an active role in integrating internal and external offerings within the owned platform architecture (similar to the “transform”strategy).

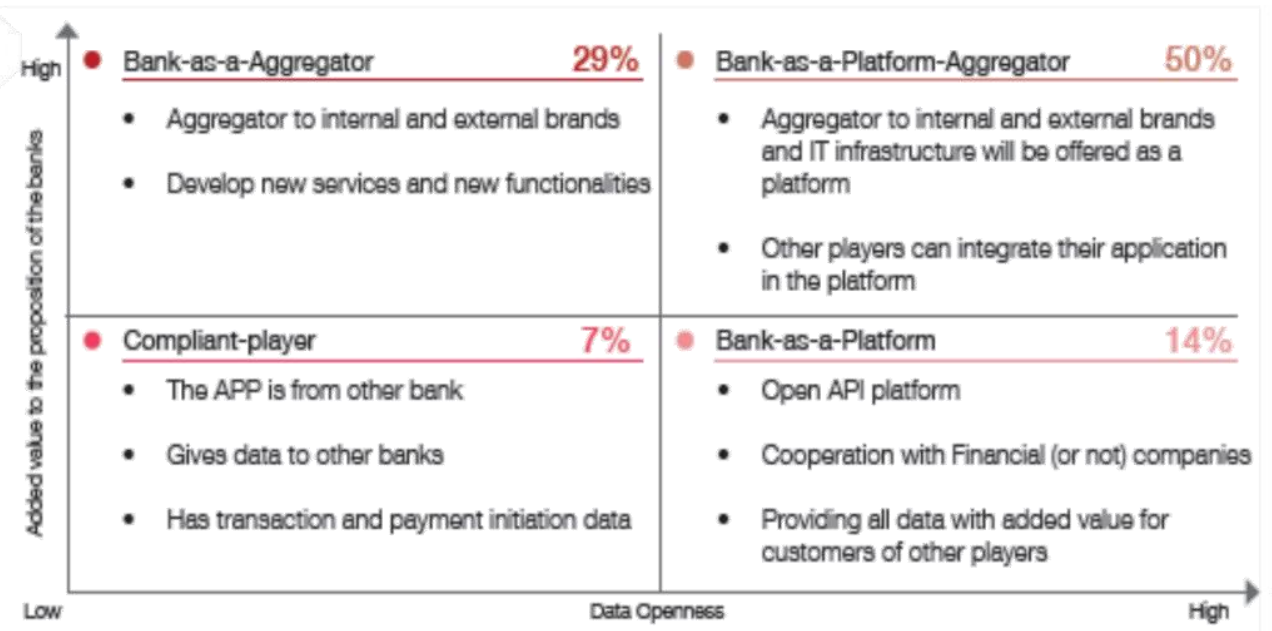

Figure 1. Which strategic positioning are Banks aiming to achieve in the long term?

Source: PWC (2017b). Waiting until the Eleventh Hour. European banks reaction to PSD2, Report, p.4 
The $\mathrm{PwC}$ report shows that (2017b, p. 5) half of banks aspire to be a platform aggregator, which would mean developing an open platform that allows partners to integrate their products and services into the bank's offering while providing an open platform for generating new products and services based on the bank's API and data. (...) However, the reality is that only a handful of large banks could reasonably expect to build a truly powerful partner ecosystem. In fact, we doubt that many third parties will be willing to connect to multiple banks as long as there is no common API standard across Europe. Third parties will instead turn to data consolidators to accomplish this cumbersome job for them. (...) Given this reality, banks need to perform a rigorous self-assessment as they transition to the world of opening banking, including their market positioning and competitive strengths. Further, they need to analyze their products and services portfolio and determine their disintermediation risk for each product and service they offer. Additionally, factors such as capital requirements and various risks (such as operational and IT risks) might need to be analyzed to determine in which areas and how actively a bank should push an open banking approach.

\section{The BBVA Case}

Banco Bilbao Vizcaya Argentaria, better known as BBVA, is a primary international bank, headquartered in Bilbao, Spain. Founded in 1857 as Banco de Bilbao, the BBVA of today is the result of an intense merger and consolidation activity throughout the whole $20^{\text {th }}$ Century. In particular, since the second half of the $1990 \mathrm{~s}$, the bank has experienced a strong international expansion through this intense activity. In this period, the strategy of BBVA shifted toward increasing its footprint and diversification in high-growth markets. While having reached the dimensions of a global actor, at the beginning of the 2000s, BBVA integrated all the different entities that composed its universe under one, unique, BBVA entity, with the aim of simplifying the complexity that arose from its buoyant expansion. In addition, through this process, the bank aimed at creating a unique, appealing brand for all its activities. The serial consolidation activity among smaller banks and acquisition of other players not only in Spain, but mainly beyond national borders, allowed BBVA to achieve a sound geographic diversification through relevant presence both in developed (European Union and United States) and emerging markets (Turkey and Mexico in particular). In this process, the bank demonstrated that good organisational and corporate management capabilities were embedded within the company. In fact, BBVA distinguished itself in the expansion process by quickly integrating and harmonising different realities with diverse client bases, infrastructures and channels. The focus of the bank would remain indeed on superior, consistent, customer experience, an aspect on which BBVA prides itself. Currently, the bank is present in over 30 countries inside and outside the European Union, with a particular position of strength, outside Spain, in the United States, Latin America (especially Mexico), and Turkey. The bank employs 132,000 people that serve over 72 million customers, with approximately 690 billion Euros in balance sheet assets. The bank offers a thorough range of products and services across a universal banking model that spans from retail banking (accounts, payments, loans and mortgages, plans and investment funds, insurance...) to corporate and investment banking (markets, investment banking, transaction services...). The BBVA vision entails the customer at the very centre of attention, and is articulated as follows (BBVA, 2017):

"Offering the best banking solutions, in accordance with their (customers') needs".

"Helping them (customers) make better financial decisions".

"Having a positive impact on people's lives and companies' activities".

After the crisis, the bank heavily invested in digital development and improving its technological infrastructure. The bank recognised the importance of new digital paradigms to compete effectively. An enriched digital proposition, along with new ways of customer interaction was considered being a crucial aspect to achieve success within the banking industry. BBVA has progressively embedded digitality within its vision for the future, trying to increase revenues from digital products and services. Customer relationships is preserved in the vision of the bank, by keeping on satisfying ever-shifting customer needs, to be a "bank of the $21^{\text {st }}$ Century" (BBVA, 2017). In this period, BBVA top management stressed how digital priorities passed through:

1) Renewed channels.

2) Driving sales of digital bank and non-bank products.

3) Entry in new segments also through collaboration with Fintechs.

4) Transformation in culture, teamwork, and artefacts to foster the development of new solutions and innovative

1 BBVA. (2017). BBVA-Corporate Information is retrieved from the website: https://www.bbva.com/en/corporate-information/ 
thinking.

Given that, BBVA has worked at reshaping its offering radically, pursuing new opportunities in accordance with its strong growth vocation. This implied both the collaboration and cooperation with external partners and the internal development of new solutions. In the first case, for instance, in 2014 BBVA acquired Simple, a US-based non-bank start-up, yet providing account and banking services with mobile channels through the partnership with Bancorp - a back-end institution. Afterwards, BBVA managed to integrate the offering of Simple within its banking infrastructure from Bancorp's one. In 2015 instead, BBVA invested in a controlling stake in Atom, a mobile-only bank headquartered in UK. This investment in what was deemed, at the time, one of the most innovative Fintech realities in Europe, was presented by the top management as an opportunity for BBVA to be a player in the future of banking. In addition, the bank has often been participating, as an investor, in new ventures in Silicon Valley through a dedicated Venture Capital arm. With respect to internally-developed solutions instead, BBVA has intervened by organising itself around the development and nurturing of new distinctive resources and capabilities. In fact, the company has created separate organisational structures, with more flexible rules and a Silicon-Valley-like culture to foster innovative thinking. Those structures have the specific mission of improving the bank's digital proposition and addressing customer feedback to improve the experience in the use of digital solutions (CapGemini, Linkedin, EFMA, 2018).

Within its specific vision on digitality, BBVA has aimed in the last 10 years at developing a positioning based on innovativeness and differentiation, while remaining present in all the traditional segments of retail banking, corporate and investment banking. The plan formulated between 2015 and 2016 encompasses priorities across different dimensions:

- Enhanced customer experience, with renewed attention to digital customer journeys across products and services.

- Increased digital sales, as they are an incredible opportunity of growth, and developing the proper metrics to assess digital performance.

- Developing alternative business models, especially encompassing collaboration and cooperation with new Fintech players.

- Efficient capital allocation across different lines of business and different projects.

- Efficiency in execution, through the simplification of processes and activities.

- Selective hiring policy to on-board the brightest workforce, fostering innovation and the development of knowledge and distinctive competencies.

The achievement of these objectives, along with specific measures, should be supported by effective internal and external organisational practices for the bank to be successful both in the short-term and long-term through long-lasting customer relationships. In particular, BBVA deemed the development of new competences as a key driver for innovation, an enhanced proposition, and hence, value appropriation. In fact, a specific function has been created within the organisational chart of the bank. This function is in charge, among other tasks, of Data Management and Open Innovation. The current organisational structure hence supports the dual goal of continuously developing distinctive capabilities for long-term sustainability, while ensuring smooth operational efficiency in a business-as-usual setting through paying attention to the execution and performance goals.

It is within this specific business, strategic, and organisational setting, the rise of Fintech, the introduction of PSD2, and the Open Banking models, that the company also started to think about the adoption of a platform approach to pursue new revenue streams and explore innovative solutions, namely the API_Market.

\subsection{BBVA-as-a-Platform: The API_Market Initiative}

This initiative, launched to the wider public between 2016 and 2017, took the specific form of an API Marketplace, indeed denominated “BBVA API_Market (https://www.bbvaapimarket.com/):

API_Market is a global and open API platform that lets you easily access financial solutions and seamlessly implement them in your company. (...) It is a platform of financial APIs from different BBVA entities or countries. Companies or developers interested in using the APIs can sign up and test them in a Sandbox environment. (...) The platform is targeted towards companies, small businesses and developers. Anyone interested in building value-added services based on financial APIs. The aim is to establish long-term relationships of trust between $B B V A$ and its customers. One of the primary considerations for being eligible to access the APIs in production environment is to have a professional business proposal. (...) The customer does not need to be a BBVA customer to work with our APIs. He/she only need to sign up in BBVA API_Market to access sandbox environment. 
In practice, API_Market represents a platform with which different sides of users get in contact and, in particular, Fintechs and other third parties can access data and information and plug into BBVA's data and banking core services through open interfaces.

The initiative has its roots in the beginning of the 2010s. In reality, the concept of API was not new to banks at the time. Those interfaces were used most internally to ensure that different elements within the infrastructure of the bank could communicate among themselves. This interconnection was indeed a crucial element to run smoothly processes that entailed different nodes. In fact, several banks had reflected on the role and potentialities of APIs, in particular of APIs which could be opened to third parties. In the specific case of BBVA, this process took between 6 and 7 years to reach a viable proposition.

The path towards an open API platform at BBVA started first with the approaching of developers in a way that was common to many banks at the time: Hackatons. Actually, BBVA was trying to enrich its value proposition through apps that could communicate with its systems and be integrated in it. After successful initiatives of this kind in Madrid and Barcelona, BBVA also launched Hackatons in Mexico with great success.

Once approached the developers, BBVA decided to see whether it could be viable to integrate with external players easily and with high security standards, while letting third parties access the core of its banking infrastructure and data. In the case of Hackatons, BBVA opened one of its APIs to developers. Along with this step, BBVA used an outsourced API Manager, a system that helped in keeping APIs under control, with particular respect to security, managing the operation of APIs, interaction with the developer community, and analysing the usage of APIs. The warm liking from developers is what subsequently triggered a wider reasoning about the extent to which APIs could be opened, examining a market opportunity for an open platform.

Given the market situation, the bank started exploring how it could generate new revenue streams, and they took the decision towards a multi-sided platform in which banking and non-banking services could have been developed. Some conditions were eligible to choose this direction and they can be synthetized as follows:

- The presence of a nascent ecosystem around payments and banking services that, at the same time, could threaten a pipeline business model and could foster innovation and a renewed experience, to enhance the value proposition and, hence, profits.

- Reduction in costs of innovation through on boarding external partners to invest in products/services developed through the platform. That would have generated economies of scope in innovation around a core of highly-reusable elements for a variety of purposes.

- The possibility to increase and diversify the bank's revenue streams because banking and non-banking services are developed. These revenues come from the business side when developers and third parties leverage the BBVA platform through APIs for developing and selling their products. This offers a significant upside as it could refer to any possible sector within which a third party need to plug into a bank's data or services. This stream of revenues would be dependent on the platform usage and services sold to other financial and non-financial businesses. The second stream of revenues is from additional added-value services embedded and aggregated within the offering of BBVA which can deliver a superior customer experience.

A practical example of those two streams of revenue would be instant loans. Those would be requested and accepted as the customer makes purchases from a third-party that is using the platform. Loans experience would be innovated and aggregated with new services. BBVA makes money on the usage of the API that connects to the loan module. In addition, BBVA can make money from the loan conceded to the customer. As a remark on the second type of revenue stream, it should be noted that, rather than on an explicit charge, it also could pass through an indirect mechanism of customer acquisition, satisfaction, and retention due to the enhanced value proposition, and a subsequent cross/up-selling of services. In this case, the only explicit charge would be the rather traditional interest rate. However, the aggregation of banking products has generated the opportunity to sell the loan and has made the customer experience more seamless, improving satisfaction and, hence, retention.

\section{Conclusions}

The main idea is that retail banks should leverage from the increasing power and the digital age instead of running behind them; this is the meaning from running to changing a bank business model. What customers regret from banks is that they have not yet been able to increase their capacity to interact but not only in a sense of developing new channels/accesses to banks but developing a double way communication in which according to many data a bank owns from their customers it is able to react fitting their requests. One of the main problem 
related to the so-called disruptive technologies is that it is difficult to determine the best way to exploit them, which should be bank-specific because each bank holds its own positioning in the market. The issue is that if the cost benefit has to prevail over the rewarding benefits or vice versa. The idea of technology in terms of exploiting it because of low cost attitude can be a false friend to many business model, especially when they need to self-sustain themselves. This misunderstanding is visible because often bank managers think of technology in terms of convenience. However, this word can have different meaning such as the followings: advantage, suitability, advisability, but also comfort, coziness, ease, amenity, leisure or even the meaning of advantage, benefit, plus, profit and asset. In the way, we interpret and put its meaning into a value proposition the idea behind it can change dramatically. Beyond the 'stay in the game' pressures of compliance, there are the 'win the game' pressures created by time-to-market drivers that include rapid track development of new retail banking products to match competitors. Therefore, a way to stay in the game can be Open Banking, which is both a threat and an opportunity for traditional financial institutions. The threat comes from the fact that banks will no longer be able to control their interaction with their customers (Omarini, 2015). In practice, this means that instead of doing all of their banking through one or two firms, customers could have their current account with one provider and then bolt on other financial services such as an insurance, mortgage and investments through other providers, all under the user interface of their choosing. To stay ahead of the competition banks need to embrace innovation and there are a number of strategies banks can develop. Put this way, Open Banking can be considered an opportunity for banking to diversify and innovate their offering. In doing this, banks and financial institutions can work. APIs show to be the heart of Fintech revolution but the added value is that each bank or financial institution can access a lot of data sources that generate a large volume of information available and valuable to reshape their business models. Given all that above, an ingredient lies and remain important in the new financial system, that is trust (in banks, Fintechs, Techfins, regulators and users), and it is the key word around which this revolution revolves. The financial system is experiencing a new era: new business models with concepts that are transforming the financial culture: APIs, blockchain, big data, Fintech, etc. This entire new world must be regulated to avoid systemic abuse and risks. The problem is that innovation is global and fast, while regulation is local and slow. The integration between banks and Fintech on an open platform is a new model for banks to scale up innovation, because banks can leverage on the breadth of offering, achieve an interesting growth, and be back to compete in the market arena.

There are many other interesting examples of Open Banking, such as that of HSBC's - Connected Money -, which allows customers to see their accounts at up to 21 different banks in one place, also offering new services enabled by the Open Banking initiative. Another one is that of Barclays. In Italy, a medium bank group - called Gruppo Sella - has developed Fabrick, which is an open financial ecosystem that enables and fosters a fruitful exchange between players that discover, collaborate and create innovative solutions for end customers, through the API platform. Fabrick Platform is the technological backbone empowering the Fabrick ecosystem, connecting its players to enable their business models and use-cases, where traditional and new players collaborate (such as Fintechs, System Integrator, Digital Factory, etc.) with an international vision to close the gap in the Italian open banking experience.

In a few years, the difference will not be between big banks winning or Fintechs winning and vice versa, it will be between which banks and Fintechs invested successfully in becoming the most customer-centric and those that that did not do it.

\section{References}

Arner, D., Barberis, J., \& Buckley, R. (2015). The evolution of fintech: a new post-crisis paradigm?

Ayadi, R., Arbak, E., \& De Groen, W. (2011). Business Models in European Banking. A pre- and post-crisis screening. Centre for European Policy Studies.

Ayadi, R., De Groen, W., Sassi, I., Rey, H., \& Aubry, O. (2015). Banking Business Models Monitor 2015 Europe. Centre for European Policy Studies Brussels and International Observatory on Financial Services Cooperatives, HEC Montréal.

Ayadi, R., Arbak, E., \& De Groen, W. (2014). Ayadi, R., Arbak, E., De Groen, W. P. (2014). "Banking Business Models Monitor 2014 Europe”. Centre for European PoliStudies Brussels and International Observatory on Financial Services Cooperatives. HEC Montréal.

Ayadi, R., Arbak, E., \& DeGroen, W. (2012). Regulation of European Bank and Business Models: Towards a New Paradigm. Centre for European Policy Studies. Centre for the European Policy Studies.
BBVA.
(2017)
$B B V A$
Corporate
Information.
Retrieved
from
BBVA: https://www.bbva.com/en/corporate-information/ 
Blake, M., \& Vanham, P. (2016, November 30). 5 things you need to know about fintech. Retrieved from World Economic Forum: https://www.weforum.org/agenda/2016/04/5-things-you-need-to-know-about-fintech/

Brainard, L. (2017). Where Do Banks Fit in the Fintech Stack? Retrieved October 21, 2017, from https://www.federalreserve.gov/newsevents/speech/brainard20170428a.htm

Broeders, H., \& Khanna, S. (2015, January). Strategic choices for banks in the digital age. McKinsey Quarterly Review. Retrieved October 21, 2017, from http://www.mckinsey.com/industries/financial-services/our-insights/strategic-choices-for-banks-in-the-digit al-age

CapGemini, Linkedin, EFMA. (2018). World Fintech Report. Retrieved June 8, 2018, from https://www.capgemini.com/wp-content/uploads/2018/02/world-fintech-report-wftr-2018.pdf

Cernov, M., \& Urbano, T. (2018, June). Identification of EU bank business models a novel approach to classifying banks in the EU regulatory Framework. EBA Staff Paper Series, N. 2, EBA Staff Paper.

Chen, Z., Li, Y., Wu, Y., \& Luo, J. (2017). The transition from traditional banking to mobile internet finance: an organizational innovatio perspective - a comparative study of Citibank and ICBC. Financial Innovation, $3(12)$.

Chesbrough, H. W. (2003). Open Innovation: The new imperative for creating and benefiting from technology. Boston: Harvard Business School Press.

Chesbrough, H. W. (2006). Open Business Models: How to Thrive in the New Innovation Landscape. Boston: Harvard Business School Press.

Chesbrough, H. W. (2011). Open Services Innovation: Rethinking your Business to Grow and Compete in a New Era. San Francisco: Wiley.

Chesbrough, H. W., Vanhaverbeke, W., \& West, J. (2014). New Frontiers in Open Innovation. Oxford: Oxford University Press. https://doi.org/10.1093/acprof:oso/9780199682461.001.0001

Chishti, S., \& Barberis, J. (2016). The Book of Fintech. Wiley. https://doi.org/10.1002/9781119218906

Citibank. (2016). Citi Global Perspectives \& Solutions (2016) Digital Disruption. How Fintech is forcing banking to a tipping point. Retrieved June 21, 2017, from https://www.privatebank.citibank.com/home/fresh-insight/citi-gps-digital-disruption.html

Cortet, M., Rijks, T., \& Nijland, S. (2016). PSD2: The digital transformation accelerator for banks. Journal of Payments Strategy \& Systems, 10(1), 13-27.

de Jong, M., \& van Dijk, M. (2015, July). Disrupting beliefs: A new approach to business-model innovation. McKinsey Quarterly Review. Retrieved June 17, 2018, from retrieved On June 17, https://www.mckinsey.com/business-functions/strategy-and-corporate-finance/our-insights/disrupting-belief s-a-new-approach-to-business-model-innovation

Deutsche Bank. (2014). Fintech - The digital (r)evolution in the financial sector.

Dhar, V., \& Stein, R. (2016). FinTech Platforms and Strategy. MIT Sloan School Working Paper 5183-16, 5183-16. Retrieved October 21, 2017, from https://papers.ssrn.com/sol3/papers.cfm?abstract_id=2892098

Dirk, A., \& Zetzsche, R. P. (2017). From Fintech To Techfin: The Regulatory Challenges Of Data-Driven Financial Institutions. EBI Working Paper Series.

Drucker, P. F. (1954). The Practice of Management. New York: Harper\&Row.

ECB - European Central Bank. (2016). Joint Supervisory Teams. European Central Bank - Banking Supervision. European Central Bank. Retrieved December 21, 2016, from https://www.bankingsupervision.europa.eu/banking/approach/jst/html/index.en.html

Enkel, E., Gassmann, O., \& Chesbrough, H. W. (2009). Open R\&D and open innovation: exploring the phenomenon. R\&D Management, 39(4), 311-316. https://doi.org/10.1111/j.1467-9310.2009.00570.x

EY. (2017). Fintech Adoption Index 2017. Retrieved June 17, 2018, from http://www.ey.com/Publication/vwLUAssets/ey-fintech-adoption-index-2017/\$FILE/ey-fintech-adoption-in dex-2017.pdf

EY. (2017a). Fintech Adoption Index 2017. Retrieved June 27, 2018, from https://www.ey.com/Publication/vwLUAssets/ey-fintech-adoption-index-2017/\%24FILE/ey-fintech-adoptio 
n-index-2017.pdf

Finextra \& CA Technologies. (2016). Preparing for PSD2: exploring the business and technology implications of the new payment services directive.

FSI, F. S. (2017, June 27). Financial Stability Implications from FinTech, Supervisory and Regulatory Issues that Merit Authorities' Attention.

Gawer, A. (2014). Bridging differing perspectives on technological platforms: Toward an integrative framework. Research Policy, 43(7), 1239-1249. https://doi.org/10.1016/j.respol.2014.03.006

Gawer, A., \& Cusumano, M. A. (2014). Industry Platforms and Ecosystem Innovation. Journal of Product Innovation Management, 31(3), 417-433. https://doi.org/10.1111/jpim.12105

Investopedia. (2017). Retrieved from Investopedia: https://www.investopedia.com/terms/f/fintech.asp

Itami, H., \& Nishino, K. (2010). Killing Two Birds with One Stone - Profit for Now and Learning for the Future. Long Range Planning, 43, 364-369. https://doi.org/10.1016/j.lrp.2009.07.007

KPMG. (2017). Value of Fintech. Retrieved June 17, 2018, from https://assets.kpmg.com/content/dam/kpmg/uk/pdf/2017/10/value-of-fintech.pdf

KPMG. (2017). Value of Fintech. Retrieved June 27, 2018, from https://assets.kpmg.com/content/dam/kpmg/uk/pdf/2017/10/value-of-fintech.pdf

Magretta, J. (2002). Why Business Models Matter. Harvard Business Review, 80(5), 86-92.

Mas-Colell, A. M. (1995). Microeconomic Theory. New York: Oxford University Press.

Mention, A. L., \& Salampasis, D. G. (2018). Open innovation in financial institutions: individual and organisational considerations. International Journal Transitions and Innovation Systems, 6(1), 62-87. https://doi.org/10.1504/IJTIS.2018.090781

Microsoft Services. (2017). The Future Banking Ecosystem. Evolution and Innovation in the Digital Era. Retrieved June 15, 2018, from https://info.microsoft.com/rs/157-GQE-382/images/Microsoft_The_Future_Banking_Ecosystem.pdf

Omarini, A. (2014). Strategy and Business Models in Retail Banking: Why Should They Matter Also to Supervisors? Journal of Financial Transformation, 39, 47-58.

Omarini, A. (2015). Retail Banking. Business Transformation and Competitive Strategies for the Future. London: Palgrave MacMillan Publishers.

Omarini, A. (2016). Retail banking: a business in deep transformation. Arabian Journal of Business and Management Review, 6(4).

Omarini, A. (2018). The Retail Bank of Tomorrow: A Platform for Interactions and Financial Services. Conceptual and Managerial Challenges. Research in Economics and Management (REM), 3(2), 110-133. Retrieved from http://www.scholink.org/ojs/index.php/rem/article/view/1343

Osterwalder, A. (2013, May 6). A Better Way to Think About Your Business Model. Retrieved from Harvard Business Review: https://hbr.org/2013/05/a-better-way-to-think-about-yo

Pagani, M. (2013). Digital business strategy and value creation: framing the dynamic cycle of control points. MIS Quarterly, 37(2), 617-632. https://doi.org/10.25300/MISQ/2013/37.2.13

PwC. (2016). What is Fintech? Retrieved June 2018, from https://www.pwc.com/us/en/financial-services/publications/viewpoints/assets/pwc-fsi-what-is-fintech.pdf

PwC. (2016). What is Fintech? Retrieved December 21, 2017, from https://www.pwc.com/us/en/financial-services/publications/viewpoints/assets/pwc-fsi-what-is-fintech.pdf

PWC. (2017). Global Fintech Report 2017.

PwC. (2017a). Global Fintech Report 2017.

PwC. (2017b). Waiting until the Eleventh Hour. European banks reaction to PSD2. Retrieved January 3, 2018, from https://www.pwc.com/gx/en/financial-services/assets/pdf/waiting-until-the-eleventh-hour.pdf

Schueffel, P., \& Vadana, I. (2015). Open Innovation in the Financial Services Sector - A. Journal of Innovation Management, 3(1), 25-48. Retrieved June 27, 2018, from https://www.researchgate.net/publication/275027680_Open_Innovation_in_the_Financial_Services_Sector_ 
-_A_Global_Literature_Review?enrichId=rgreq-20faaa7a608e929520cbd84b0ac73317-XXX\&enrichSourc e=Y292ZXJQYWd1OzI3NTAyNzY4MDtBUzoyMTg3ODk0NTE5NjQ0MTZAMTQyOTE3N

Teece, D. J. (2010). Business Models, Business Strategy and Innovation. Long Range Planning, 43, $172-194$. https://doi.org/10.1016/j.lrp.2009.07.003

Yin, R. K. (2003a). Case Study Research: Design and Methods. Thousand Oaks: Sage Publications.

Zachariadis, M., \& Ozcan, P. (2017). The API economy and digital transformation in financial services: the case of open banking. SWIFT Institute.

\section{Copyrights}

Copyright for this article is retained by the author(s), with first publication rights granted to the journal.

This is an open-access article distributed under the terms and conditions of the Creative Commons Attribution license (http://creativecommons.org/licenses/by/4.0/). 